\title{
A BALEEN WHALE FROM THE PLIOCENE OF NICARAGUA
}

\author{
BALLENA DE BARBAS DEL PLIOCENO DE NICARAGUA
}

\author{
Spencer G. Lucas ${ }^{1 *}$, Samuel A. McLeod ${ }^{2}$, Lawrence G. Barnes ${ }^{2}$, \\ Guillermo E. Alvarado ${ }^{3}$, Ramiro García ${ }^{4} \&$ Edgar Espinoza ${ }^{4}$
}
${ }^{1}$ New Mexico Museum of Natural History and Science, 1801 Mountain Road N.W., Albuquerque, New Mexico 87104 USA ${ }^{2}$ Department of Vertebrate Paleontology, Natural History Museum of Los Angeles County. 900 Exposition Boulevard, Los Angeles, California 90007 USA ${ }^{3}$ Escuela Centroamericana de Geología, Universidad de Costa Rica, Apdo. 214, 2060, San José, Costa Rica ${ }^{4}$ Museo Nacional de Nicaragua, Managua, Nicaragua *Autor para contacto: spencer.lucas@state.nm.us

(Recibido: 23/09/08 ; aceptado: 12/12/09)

\begin{abstract}
An incomplete fossil skeleton of a cetacean from San Rafael del Sur in southern Nicaragua consists of 14 vertebral centra, one humerus and 10 incomplete ribs. This fossil is from the Lower Pliocene El Salto Formation and it can be identified as a balaenopterid mysticete. This is the first cetacean fossil documented from Central America and is a rare occurrence of a mysticete whale in Neogene strata of the tropical latitudes.

Keywords: Whale, mysticete, Nicaragua, El Salto Formation, Pliocene.

RESUMEN: Un fósil incompleto de cetáceo procedente de San Rafael del Sur, en la parte austral de Nicaragua, consiste en 14 vértebras centrales, un húmero y 10 costillas incompletas. Este fósil proviene del Plioceno Inferior de la Formación El Salto y puede ser identificado como perteneciente a una balaenopteridae misticeto. Este es el primer cetáceo fósil documentado América Central, y constituye una rara ocurrencia de ballenas misticetas en los niveles Neógenos de las latitudes tropicales.

Palabras clave: Ballenas, misticeto, Nicaragua, Formación El Salto, Plioceno.
\end{abstract}




\section{INTRODUCTION}

Although the first published report of fossil mammals from Central America was of fossils from Nicaragua (Leidy, 1886), much less is known of Nicaraguan fossil mammals than from any other Central American country (Lucas \& Alvarado, 1994; Lucas et al., 1997, 2007, 2008). This largely reflects a lack of exploration and study. Here, we document the partial fossil skeleton of a baleen whale from Pliocene strata in western Nicaragua (Fig. 1). This is the first cetacean fossil documented from Nicaragua and from Central America and is a rare occurrence of a mysticete whale in Neogene strata of the tropical latitudes.

\section{PROVENANCE}

The whale fossil is an incomplete skeleton on display in the Museo Comunitario de San Rafael del Sur, Nicaragua. It was discovered in July 1981 at Mine K-11 (a limestone quarry for cement) near San Rafael del Sur in strata of the El Salto Formation of Pliocene age (Fig. 2). Reshetov (1982) mentioned the existence of this whale skeleton, but provided no other information on it.

Mine K-11 is a large, abandoned open pit mine south of San Rafael del Sur at UTM 16P, 564899E, 1305906N (NAD 27). Two major lithologic units are exposed at the pit: light olive gray $(5 \mathrm{Y} 6 / 1)$ to grayish yellow green $(5 \mathrm{GY} 7 / 2)$

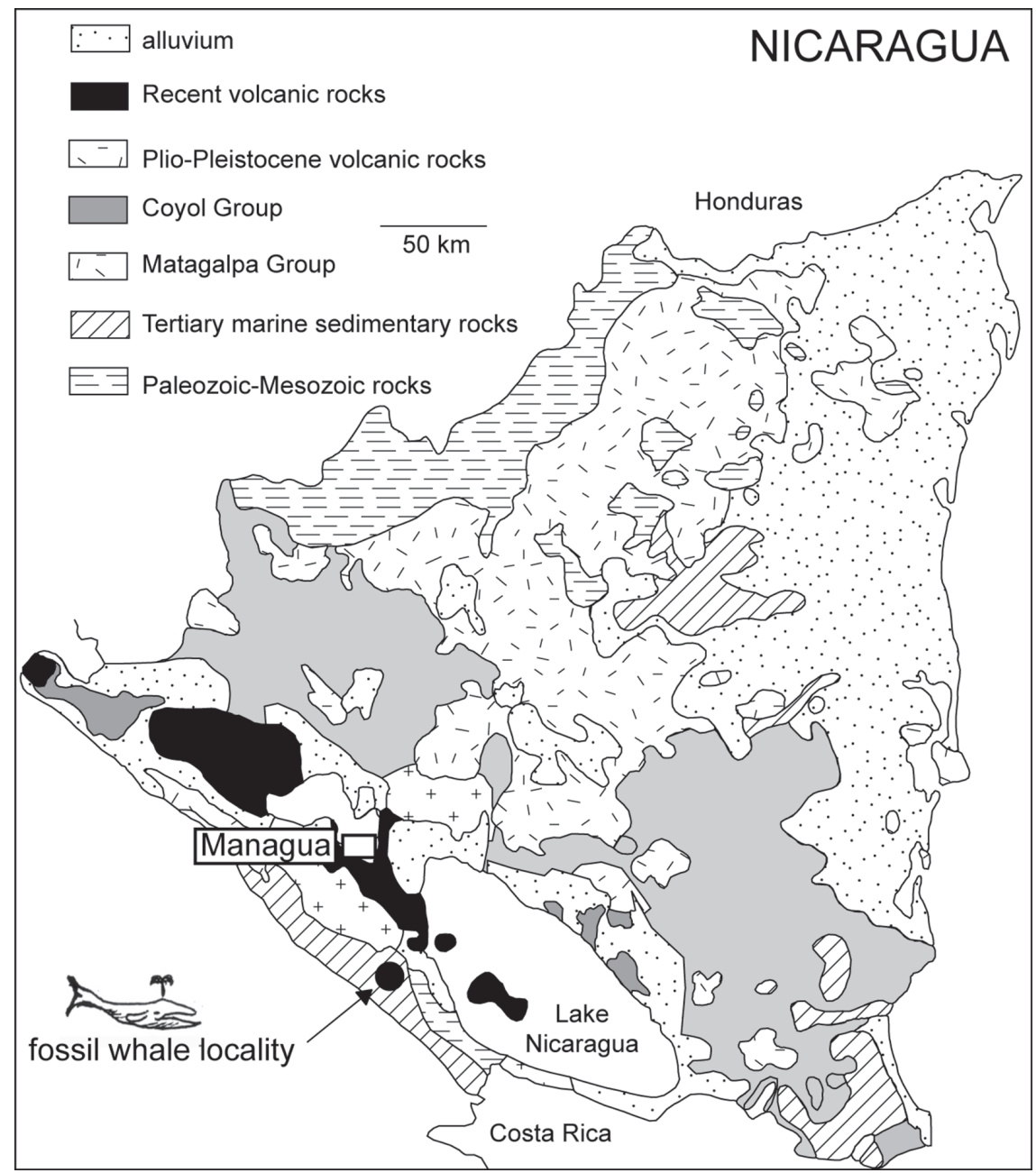

Fig. 1. Generalized geologic map of Nicaragua (after Weinberg, 1992) showing the whale locality at mine K-11. 


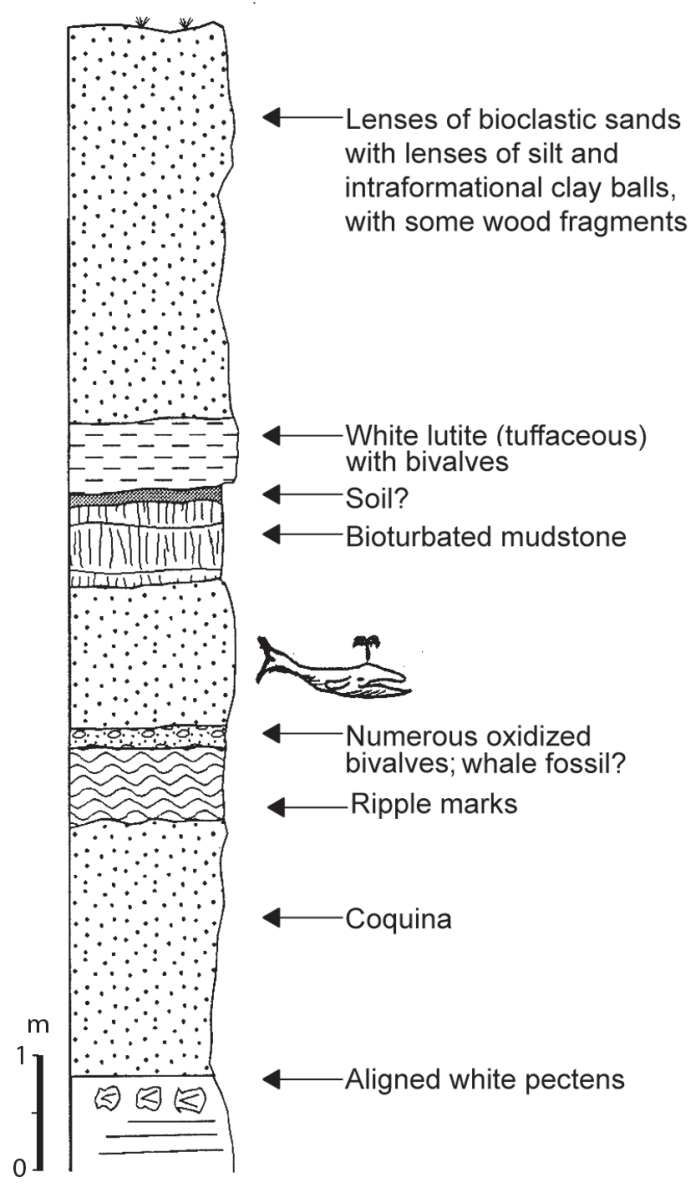

Fig. 2: Measured stratigraphic sections at the Mine K-11 locality showing stratum from which the cetacean fossil was collected.

smectitic shale overlain unconformably by oyster-bearing very pale orange (10YR $8 / 2)$ and pale yellowish orange (10YR8/6), hematitic coquinoid limestones, both of the Pliocene El Salto Formation (Fig. 2).

The El Salto Formation is up to $100 \mathrm{~m}$ thick and crops out primarily in the Sierras de Diriamba near San Rafael del Sur in southern Nicaragua. The formation consists of shelly limestone, marl and minor siltstone and sandstone and is locally mined for cement production. The El Salto Formation has long been assigned an early Pliocene age based on its molluscan fossils (e.g., Woodring, 1973; Weyl, 1980; Kirby and Jackson, 2004), but more precise age data are not available.

\section{DESCRIPTION AND IDENTIFICATION}

The whale fossil consists of 14 vertebral centra, one humerus and 10 incomplete ribs (Fig. 3; Table 1). The vertebrae of this smallto medium-sized whale are missing almost all of the neural arches and transverse processes, but the cervical vertebrae are unfused. The large and relatively long left humerus is straight, although it has a notable constriction mid shaft, and without much of an offset to the head. The greater tubercle is relatively small and low, approximately at the lower level of the head. The angle between the radial and ulnar facets is quite obtuse.

Based on the incomplete and relatively fragmentary nature of the specimen, together with a lack of diagnostic features from comparable elements in well-identified similar taxa, a generic assignment of this specimen would be dubious. The general conformation of the vertebrae and humerus, however, together with the age of the deposits from whence it came, indicate the specimen represents a less derived member of the Balaenopteridae (Pia, 1937).

Table 1

Measurements of vertebrae, based on their alignment in the exhibit (in mm). length $=$ antero-posterior length of centrum

\begin{tabular}{cccc}
\hline $\begin{array}{c}\text { Vertebral } \\
\text { position }\end{array}$ & Length & Width & Height \\
\hline Cervicals? & 80 & 200 & 146 \\
& 73 & 198 & 145 \\
& 63 & 195 & 146 \\
& 43 & 179 & 149 \\
& 55 & 176 & 155 \\
& 43 & 188 & 146 \\
& & & \\
& 156 & 200 & 128 \\
& 140 & 215 & 153 \\
& 136 & 220 & 140 \\
& 120 & 220 & 136 \\
& 110 & 205 & 144 \\
\hline
\end{tabular}

Humerus measurements (in $\mathrm{mm}$ ):Maximum length 390; Maximum proximal width 220; Maximum distal width 200. 

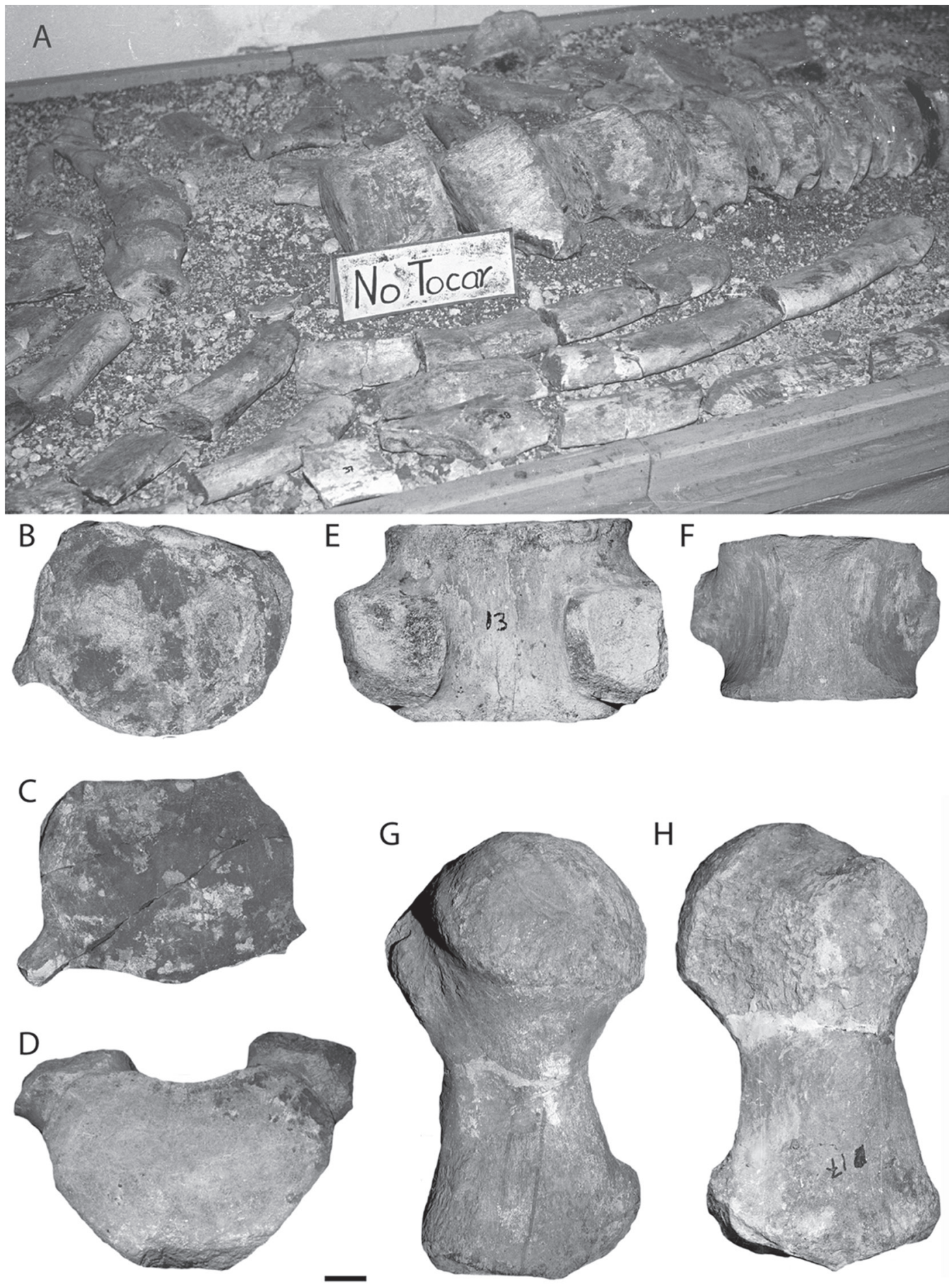

Fig. 3: Fossil of a balaenopterid mysticete cetacean from the Pliocene El Salto Formation at Mine K-11. A, Vertebrae and ribs on display. B-F, Vertebral centra. G-H. Humerus, Scale bar $=3 \mathrm{~cm}$. 


\section{DISCUSSION}

The mere presence of this mysticete whale in southern Nicaragua is interesting, for there is little to compare it to in the tropical Americas. Cetacea are in general markedly antitropical in their distribution (Davies, 1963; Barnes, 1985). In general, cetacean fossils are rarely reported from tropical latitudes, particularly baleen whale fossils. Fossil Cetacea are much more abundant and taxonomically diverse in temperate latitudes (Barnes, 1977, 1983; Fordyce et al., 1992, 1995), and this is also true for living cetaceans (Berta et al., 2006). Some exceptions to this generalization are those mysticetes that migrate annually from their primary temperate or circum-polar feeding grounds to tropical latitudes where they breed (for example Megaptera novaeangliae), and those that typically inhabit tropical latitudes year-round (for example, the tropical rorqual, Balaenoptera edeni).

Among fossil Cetacea that have been reported from tropical latitudes, Deraniyagala $(1967,1969$ a, b) reported odontocetes and mysticetes from Ceylon, and he named some extinct taxa on questionably diagnostic materials. Anderson and Barnes (2000) reported a single vertebra of a Miocene mysticete cetacean from Bangladesh. Along the Pacific coast of the Americas, Bouetel \& Muizon (2006) have reported late occurring cetotheriid and balaenopterid mysticetes from coastal Peru.

Although the Yucatán Peninsula has many thousands of meters of carbonaceous platform sediments ranging in age from Paleogene to Pliocene and despite significant field work, some of which has yielded fossil Sirenia (Domning, 1989), no fossil cetaceans have been reported from these sediments (Barnes, 1998, 1999, 2002). This curious absence of fossil Cetacea is also true for the mainland of Mexico.

The absence of records on the Mexican mainland stands in contrast to the rich Paleogene through Pleistocene record of fossil Cetacea from the Peninsula of Baja California (Barnes, 1998; 1999, 2002). For example, Upper Oligocene sediments of Baja California Sur yield a diversity of baleen-bearing mysticetes (Barnes, 1998, 1999, 2002), and lowermost Miocene sediments in Baja California Sur have yielded baleen-bearing mysticetes of moderate size (González-Barba et al.,
1996). Middle Miocene deposits farther north in Baja California have yielded two or more species of Cetotheriidae (sensu lato) (Gascón-Romero et al., 1991a, b, 1994, 1997a). The geochronologically younger, and very diverse latest Miocene Isla Cedros local fauna of Baja California contains a great diversity of Cetacea, and these include at least two species of herpetocetine Cetotheriidae and six species of Balaenopteridae (Barnes, 1984, 1991, 1992a, b, 1993; Aranda-Manteca \& Barnes, 1995; Gascón-Romero et al., 1993, 1997b), some of which are relatively small, others of which are moderate to larger in body size.

Of a similar age to the Isla Cedros deposits, and currently at about the same latitude, the Palmetto Fauna of the Bone Valley Formation in central Florida contains a small balaenopterid based on dentary remains, Balaenoptera florida$n a$, which also occurs in the younger San Diego Formation in California (Deméré, 1986; Morgan, 1994). Such distributions would not be surprising prior to the closing of the Panamanian Isthmus, and further cetacean remains from the Nicaraguan deposits could help clarify the subtropical to tropical distributions of cetaceans in the prior oceanic regime with a Panamanian seaway.

\section{ACKNOWLEDGMENTS}

The work of Lucas and Alvarado in Nicaragua was made possible by the generous support of the Museo Nacional de Nicaragua through then Director Clemente Guido Martínez, and by the assistance of Frederick Lange and his family.

\section{REFERENCES}

ANDERSON, J.S., \& BARNES, L.G., 2000: A fossil Miocene whale from the Tipam Sandstone, St. Martin's Island, Bangladesh.- Oryctos, 3: 79-84.

ARANDA-MANTECA, F.J. \& BARNES, L.G., 1995: Los mamíferos marinos de edad Mioceno Tardio en la Formación Almejas en Isla de Cedros, Baja California, México.XX Reunión Internacional para el Estudio de los Mamíferos Marinos, Sociedad Mexicana para el Estudio de los Mamíferos 
Marinos, Universidad Autónoma de Baja California Sur, La Paz, Baja California Sur, México, 18-22 April 1995, Programa y Resúmenes: 26.

BARNES, L.G., 1977: Outline of eastern North Pacific fossil cetacean assemblages.- Syst. Zool., 25(4): 321-343.

BARNES, L.G., 1983: Neogene zoogeography of North Pacific fossil cetaceans.- Bull. Marine Sci., 33(3): 777.

BARNES, L.G., 1984: Fossil odontocetes (Mammalia: Cetacea) from the Almejas Formation, Isla Cedros, Mexico.- PaleoBios, 42: 1-46.

BARNES, L.G., 1985: Evolution, taxonomy and antitropical distributions of the porpoises (Phocoenidae, Mammalia).- Marine Mamm. Sc., 1(2): 149-165.

BARNES, L.G., 1991: The fossil marine vertebrate fauna of the latest Miocene Almejas Formation on Isla Cedros, Baja California, Mexico.- Primera Reunión Internacional sobre Geología de la Península de Baja California, Universidad Autónoma de Baja California Sur, La Paz, Baja California Sur, México, April 1991, Resúmenes: 10-11.

BARNES, L.G., 1992a: The fossil marine vertebrate fauna of the latest Miocene Almejas Formation, Isla Cedros, Baja California, México.- En: CARRILLO-CHÁVEZ A. \& ÁlVAREZ-ARELLANO, A. (eds.): Primera Reunión Internacional sobre geología de la Península de Baja California.Memorias, Universidad Autónoma de Baja California Sur, La Paz, Baja California Sur, México: 147-166.

BARNES, L.G., 1992b: Latest Miocene marine vertebrates from the Almejas Formation, Isla de Cedros, Baja California, México.J. Vert. Paleont., 12 (3): 18A.
BARNES, L.G., 1993: Vertebrados marinos fosiles de la Formación Almejas en Isla de Cedros, Baja California, México.- V Congreso Latinoamericano de Ciencias del Mar, Universidad Autónoma de Baja California Sur, La Paz, Baja California Sur, 27 September - 1 October, Abstracts and Program: 139.

BARNES, L.G., 1998: The sequence of fossil marine mammal assemblages in México, En: CARRANZA-CASTAÑEDA, O \& CÓRDOBA-MÉNDEZ, D.A. (eds.): Avances en investigación. paleontología de vertebrados.- Instituto de Investigaciones en Ciencias de la Tierra, Universidad Autónoma del Estado de Hidalgo, Pachuca, Hidalgo, México, Publicación Especial 1: 26-79.

BARNES, L.G., 1999: Compendio del Regístro fósil de cetáceos marinos de México.- XXIV Reunión Internacional para el Estudio de los Mamíferos Marinos, Sociedad Mexicana para el Estudio de los Mamíferos Marinos, Mazatlan, Sinaloa, México, 18-22 April 1999, Programa y Resúmenes: 17.

BARNES, L.G., 2002: Evolutionary history of the fossil marine mammals of México. En: MONTELLANO-BALLESTEROS, M. \& ARROYO-CABRALES, J. (eds.): Avances en los estudios paleomastozoologicos.Coleccion Cientifica, Serie Arqueologia, Instituto Nacional de Antropología e Historia, México, D.F., México: 125-225.

BERTA, A., SUMICH, J. L. \& KOVACS K.M., 2006: Marine mammals: Evolutionary biology, $2^{\text {nd }}$ Edition.- 560 págs. Academic Press, New York.

BOUETEL, V. \& MUIZON, C. DE, 2006: The anatomy and relationships of Piscobalaena nana (Cetacea, Mysticeti), a Cetotheriidae s.s. from the early Pliocene of Peru.Geodiv. 28(2): 319-395. 
DAVIES, J.L., 1963: The antitropical factor in cetacean speciation.- Evol., 17(1): 107-116.

DEMÉRÉ, T.A., 1986: The fossil whale, Balaenoptera davidsonii (Cope, 1982), with a review of other Neogene species of Balaenoptera (Cetacea: Mysticeti).- Marine Mamm. Sci., 2(4): 277-298.

DERANIYAGALA, P.E.P., 1967: Some new Miocene vertebrates from Ceylon.- Ceylon Assoc. Advance. Sci. Proc. $23^{\text {rd }}$ Ann. Sess. 1: 50 .

DERANIYAGALA, P.E.P., 1969a: A Miocene vertebrate faunule from the Malu Member of Ceylon.- Spolia Zeylanica (Ceylon), 31(2):551-570.

DERANIYAGALA, P.E.P., 1969b: Some Miocene vertebrates from Ceylon.- J. Palaeont. Soc. India, 13: 20-23.

DOMNING, D.P., 1989: Fossil Sirenia of the west Atlantic and Caribbean region. III. Xenosiren yucateca, gen. et sp. nov.- J. Vert. Paleont., 9(4): 429-437.

FORDYCE, R.E., BARNES, L.G., OKAZAKI, Y., KIMURA, M., HASEGAWA, Y., MCLEOD, S.A., HORIKAWA, H., GOEDERT, J.L. \& MIYAZAKI, S., 1992: Summary of taxa and geologic and geographic distributions of fossil Cetacea in the Pacific realm.- $29^{\text {th }}$ International Geological Congress, Kyoto, Japan, August, 1992, Abstracts, 2: 349.

FORDYCE, R. E., BARNES, L.G. \& MIYAZAKI, N. 1995: General aspects of the evolutionary history of whales and dolphins.- The Island Arc, 3(4): 373-391.

GASCÓN-ROMERO, G.A., ARANDAMANTECA, F. J. \& BARNES, L.G., 1991a: Una nueva evidencia de la evolución de las ballenas barbadas en Baja California.- XVI
Reunión Internacional para el Estudio de los Mamíferos Marinos, Nuevo Vallarta, Nayarit, México, April 1991, Programa y Resúmenes: 4.

GASCÓN-ROMERO, G.A., ARANDAMANTECA, F.J. \& BARNES, L.G., 1991b: Una nueva evidencia de la evolución de las ballenas barbadas en Baja California.- Primera Reunión Internacional sobre Geología de la Península de Baja California, Universidad Autónoma de Baja California Sur, La Paz, Baja California Sur, México, April 1991, Resúmenes: 31-32.

GASCÓN-ROMERO, G.A., ARANDAMANTECA, F. J. \& BARNES, L.G., 1993: Mysticetos del Mioceno Tardio-Plioceno Temprano de la Formación Almejas, Isla de Cedros, Baja California, México.Memoria del IV Congreso Nacional de Paleontología, Sociedad Mexicana de Paleontología, A.C., México City, México, 20 - 22 October 1993: 37-38.

GASCÓN-ROMERO, G.A., ARANDAMANTECA, F. J. \& BARNES, L.G., 1994: Nueva evidencia de la evolución de las ballenas barbadas en Baja California.- Rev. Invest. Cient. 2(2): 1-9.

GASCÓN-ROMERO, G.A., ARANDAMANTECA, F.J. \& BARNES, L.G., 1997a: Dos especies de cetoterios (Cetacea: Mysticeti) del Mioceno Medio de Baja California, México.- XXII Reunión Internacional para el Estudio de los Mamíferos Marinos, Sociedad Mexicana para el Estudio de los Mamíferos Marinos, Nuevo Vallarta, Nayarit, México, 27 April 1 May 1997, Programa y Resúmenes: 39.

GASCÓN-ROMERO, G.A., ARANDAMANTECA, F.J. \& BARNES, L.G., 1997b: Siete especies de balaenopteridos (Cetacea: Mysticeti) del Mioceno Tardio de Baja California, México.- XXII Reunión 
Internacional para el Estudio de los Mamíferos Marinos, Sociedad Mexicana para el Estudio de los Mamíferos Marinos, Nuevo Vallarta, Nayarit, México, 27 April 1 May 1997, Programa y Resúmenes: 41.

GONZÁLEZ-BARBA， G., CRUZ-MARIN, A., BARNES, L.G., \& PIÑEDAGERALDO, A., 1996: Primer registro de un misticeto muy primitivo en el área sur de La Paz, Baja California Sur, México.XXI Reunión Internacional para el Estudio de los Mamíferos Marinos, Sociedad Mexicana para el Estudio de los Mamíferos Marinos, El Colegio de la Frontera Sur, Chetumal, Quintana Roo, México, 8-12 April 1996, Programa y Resúmenes: 55.

KIRBY, M.X. \& JACKSON, J.B.C., 2004: Extinction of a fast-growing oyster and changing ocean circulation in Pliocene tropical America.- Geology, 32: 1025-1028.

LEIDY, J., 1886: Toxodon and other remains from Nicaragua.- Proc. Acad. of Nat. Sci. Phil., 1886: 275-277.

LUCAS, S.G. \& ALVARADO, G.E., 1994: The role of Central America in land-vertebrate dispersal during the Late Cretaceous and Cenozoic.- Profil, 7: 401-412.

LUCAS, S.G., ALVARADO, G.E. \& VEGA, E., 1997: The Pleistocene mammals of Costa Rica.- J. Vert. Paleont., 17: 413-427.

LUCAS, S.G., ALVARADO, G.E., GARCIA, R., ESPINOZA, E., CISNEROS, J.C. \& MARTENS, U., 2007: Vertebrate paleontology. En:
BUNDSCHUH, J. \& ALVARADO, G.E. (eds.): Central America: Geology, resources and hazards. Taylor \& Francis, London: 443-451.

LUCAS, S.G., GARCÍA, R., ESPINOZA, E., ALVARADO, G.E., HURTADO DE MENDOZA, L. \& VEGA, E., 2008. The fósil mammals of Nicaragua. -En: LUCAS, S.G., MORGAN, G.S., SPIELMANN, J.A. \& PROTHERO, D.R. (eds.): Neogene Mammals. New Mexico Museum of Natural History and Science, Bull. 44: 417-429.

MORGAN, G.S., 1994: Miocene and Pliocene marine mammal faunas from the Bone Valley Formation of central Florida.- Proc. San Diego Soc. Nat. Hist., 29: 239-268.

PIA, J., 1937: Von den Walen des Wiener Miozäns.- Mitteil. Geol. Gesellschaft Wien, 29: 357-428.

RESHETOV, V.J., 1982: Reporte preliminario sobre la observación de la paleontología de Nicaragua: - 13 págs. National Museum of Nicaragua, Managua.

WEINBERG, R.F., 1992: Neotectonic development of western Nicaragua.- Tectonics, 11: 1010-1017.

WEYL, R., 1980: Geology of Central America. Second, completely revised edition.- 371 págs. Gebrüder Borntraeger Berlin.

WOODRING, W.P., 1973: Affinities of Miocene marine molluscan faunas of Pacific side of Caribbean.- Est., Coast. Shelf Sci., 35: 179-190. 